\title{
MANIPULATING INCANTATION TEXTS: EXCURSIONS IN REFRAIN A*
}

\author{
By ERICA C. D. HUNTER
}

On 9 October 1851 the British Museum purchased eight incantation bowls from Col. Henry Rawlinson. ${ }^{1}$ Of these, seven were written in Aramaic. ${ }^{2}$ They were recorded by the Minutes of the Trustees of the British Museum as coming from "a tomb at Babylon", per se a most unusual provenance since incantation bowls are usually associated with domestic loci. ${ }^{3}$ The seven incantation bowls all name the same male client, one Mahperoz son of Hindo. Palaeographic studies on the typical Babylonian Aramaic script in which they were written reveal that they were the product of the same hand. ${ }^{4}$ The physical typology of the incantation bowls (hemispherical in form with simple rims measuring $0.6 \mathrm{~cm}$ thick and shaved bases) suggests that all seven were selected from the same workshop, and possibly even from the same batch of pottery. ${ }^{5}$ In such a situation, where the incantation bowls clearly form a group and were written for a single client, one might expect the texts to be duplicates.

Four of the seven bowls purchased from Rawlinson were inscribed with a common incantation text that Ben Segal has designated as Refrain A. ${ }^{6}$ This commences with a distinctive call for the overthrow of the world and heavenly order as well as the reversal of female cursers. ${ }^{7}$ Over the past one hundred and fifty years a dozen examples of this text have have come to light in a variety of international museums and private collections. The largest group is that of the British Museum which has no less than eight examples, ${ }^{8}$ including the four Rawlinson bowls as well as a small flat-bottomed stopper that Hormuzd Rassam obtained from Sippar during the excavations which the British Museum conducted at that site between 1881 and $1882 .{ }^{9}$ The remaining four examples of Refrain A are in the Iraq Museum, Baghdad, ${ }^{10}$ the Institute of Archaeology at the Hebrew University of Jerusalem, ${ }^{11}$ and in collections of antiquities that are owned by the Churchs' Ministry amongst the Jewish People, St Albans, England, ${ }^{12}$ and Near Eastern Fine Arts, New York, U.S.A. ${ }^{13}$

Specimens inscribed with Refrain A were amongst the earliest incantation bowls to be published. Two of the Rawlinson group belonging to this genre were included by Austin Henry Layard in

\footnotetext{
* The author thanks the British School of Archaeology in Iraq for financial assistance that enabled her to study IM 9726 at the Iraq Museum, Baghdad. She would also like to thank Dr Mu'ayyid Sa'id Damerji, formerly DirectorGeneral of the State Organization for Culture and Heritage, Republic of Iraq, for his generous assistance. She would also thank Dr John Curtis, Dr St John Simpson and Dr Irving Finkel of the Department of Western Asiatic Antiquities, British Museum for their assistance during her researches. Thanks are also due to Mr James Stedeford, of the Churchs' Ministry amongst the Jewish People, for enabling the Pearson bowl to be examined and photographed.

${ }^{1}$ British Museum, Trustees Minutes 1848-52, 362-3.

${ }^{2} \mathbf{B M}^{\mathrm{R}}$ 91716, $\mathbf{B M}^{\mathrm{R}} 91719, \mathrm{BM}^{\mathrm{R}}$ 91720, $\mathrm{BM}^{\mathrm{R}}$ 91721, $\mathrm{BM}^{\mathrm{R}}$ 91726, $\mathbf{B M}^{\mathrm{R}}$ 91727, $\mathrm{BM}^{\mathrm{R}}$ 91756. In this paper incantation bowls belonging to the group purchased from Rawlinson are denoted by the siglum $\mathrm{BM}^{\mathrm{R}}$.

${ }^{3}$ A. H. Layard, Discoveries in the Ruins of Nineveh and Babylon (2 vols.; London, 1853) 509 appears to have been misinformed when he stated that the eight specimens were "obtained at Baghdad, where they are sometimes offered for sale by the Arabs; but it is not known from what sites they were brought."

${ }^{4}$ The name Mahperoz includes an epithet of several Sasanian monarchs and points to the infiltration of Persian nomenclature amongst the Aramaic-speaking citizens of Babylon.
}

${ }^{5}$ For discussion of the physical typology of incantation bowls, see Erica C. D. Hunter, "The typology of the incantation bowls: physical features and decorative aspects" in J. B. Segal, with a contribution by Erica C. D. Hunter, Catalogue of Aramaic and Mandaic Incantation Bowls in the British Museum (London, 2000) 163-88, specifically 165-8.

${ }^{6}$ Segal, op. cit., 22.

${ }^{7}$ These are $\mathrm{BM}^{\mathrm{R}} 91716, \mathrm{BM}^{\mathrm{R}}$ 91720, $\mathrm{BM}^{\mathrm{R}} 91721$ and $\mathrm{BM}^{\mathrm{R}} 91727$.

${ }^{8} \mathrm{BM}^{\mathrm{9}}$ 91713, $\mathrm{BM}^{\mathrm{R}}$ 91716, $\mathrm{BM}^{\mathrm{R}} 91720, \mathrm{BM}^{\mathrm{R}}$ 91721, $\mathrm{BM}^{\mathrm{R}}$ 91727, BM 91745, BM 91758 and BM 117883.

${ }^{9}$ For further details about BM 117883 and the excavations at Sippar see Hunter in Segal, op. cit., 164.

${ }^{10}$ See Erica C. D. Hunter, "Two incantation bowls from Babylon", Iraq 62 (2000) 139-47 for IM 9726.

"See Joseph Naveh and Shaul Shaked, Amulets and Magic Bowls: Aramaic Incantations from Late Antiquity (Leiden, 1985) 134-45.

${ }^{12}$ This incantation bowl is termed the "Pearson bowl" in the discussion. It was originally published by Markham Geller, "Eight incantation bowls", Orientalia Lovaniensia Periodica 17 (1986) 101-5, and has been republished by Hunter, op. cit.

${ }^{13}$ Edwin Yamauchi, "Aramaic magic bowls", Journal of the American Oriental Society 85 (1965) 514 notes that it belonged to Mr E. Safani of Near Eastern Fine Arts, New York. In the discussion this incantation bowl is termed the "Safani bowl". 
Discoveries in the Ruins of Nineveh and Babylon. ${ }^{14}$ However, despite much subsequent interest in incantation bowls over the next one hundred and thirty years, the first attempt at analysing Refrain A was only made by Joseph Naveh and Shaul Shaked in 1985 during their discussion of the specimen housed in the Institute of Archaeology at the Hebrew University of Jerusalem, which they published in Amulets and Magic Bowls: Aramaic Incantations from Late Antiquity. In that volume Naveh and Shaked collated five incantation bowls whose texts parallel that of AMB B2. ${ }^{15}$ These included three specimens from the British Museum, ${ }^{16}$ to which they added IM 9726 on the basis of the partial translation made by Cyrus Gordon in the 1930s during his visit to the Iraq Museum, ${ }^{17}$ and the incantation bowl that Edwin Yamauchi published.

New texts of Refrain A were released in the recent publication by Segal of the British Museum collection of incantation bowls. He included four hitherto unpublished specimens in his Catalogue of the Aramaic and Mandaic Incantation Bowls in the British Museum. ${ }^{18}$ In this monograph he also collated eleven incantation bowls written in Refrain A and in doing so expanded and revised the schema of Naveh and Shaked. ${ }^{19}$ It is undoubted that Segal's collation has contributed much to the study of Refrain A, not the least in drawing attention to the number of extant texts. However, a reassessment of his work is a desideratum following the recent publication of IM 9726 and the re-reading of the Pearson bowl, which establishes these two texts as a duplicate pair within Refrain A. Furthermore, the client, copyist and provenance information that accompanies many of the texts might also be exploited to greater advantage.

"Excursions in Refrain A" commences under the heading "History of analysis of Refrain A" with brief surveys of the schema offered by Naveh and Shaked, followed by that of Segal. It then proceeds to the major section, "Textual explorations in Refrain A", which is an analysis of the individual elements or formulae of this schema that uses the dozen incantation texts as its database. The identification of each formula is accompanied by two sub-headings: "Selection and sequence" and "Textual variants". "Selection and sequence" surveys the occurrence of the formulae in the incantation texts, with especial note being made of when they are out of sequence. "Textual variants" pays particular attention to examples of textual change and corruption. The application of this methodology initially identifies the major components of Refrain A and their transmission in the dozen incantation bowls. In doing so, "Excursions in Refrain A" provides the means for fresh discussion about the writing of incantations which is the topic of the concluding section "Manipulating Refrain A: writing incantations".

\section{History of analysis of Refrain $A$}

A concordance of the various analyses of Refrain A offered to date is presented as Table 1. Naveh and Shaked isolated a number of recurrent formulaic sections: ${ }^{20}$

(a) $h p y k^{\prime} h p y k^{\prime} \ldots+$ a list of (negative) objects to be reversed, especially the curses of relatives and other men and women;

(b) an invocation of angels, especially a group of eleven names which constitute the person of YYY the Great, and

(c) an assertion of the invocation: "All that is of the earth calls and all that is of the heaven obeys".

\footnotetext{
${ }^{14}$ Layard, Discoveries in the Ruins of Nineveh and Babylon, 514-19 for Texts II (BM ${ }^{\mathrm{R}}$ 91716) and III (BM ${ }^{\mathrm{R}}$ 91720).

${ }^{15}$ Naveh and Shaked, op. cit., 136.

${ }^{16}$ The parallel texts from the British Museum, together with an updated publication history are: (i) BM 91745 (005A in Segal, op. cit.), 4-5 first published by Moïse Schwab, "Deux vases judéo-babyloniens", Revue asiatique 2 (1892) 139-42 (Text G). Excerpts of this text were included during the survey of the British Museum collection by Gordon, op. cit., 339 where it is listed under the incorrect registration of No. 19745; (ii) $\mathbf{B M}^{\mathbf{R}} 91720$ (007A in Segal, op. cit.), 7-9 which was originally published by Thomas Ellis as Text 2 in Layard, op. cit., 438-40, (iii) $\mathrm{BM}^{\mathbf{R}} 91727$ (009A in Segal, op. cit.), 9-11 has been the subject of four translations. It was first published by Thomas Ellis as Text 3
}

in Layard, op. cit., 440-1, re-edited in 1890 by Moïse Schwab, "Les coupes magiques et l'hydromancie dans l'antiquité orientale", Proceedings of the Society for Biblical Archaeology, April 1890, 306-10 (Text B), then by Isak Jeruzalmi in his unpublished doctoral thesis, "Les coupes magiques araméennes de Mésopotamie" (University of Paris, 1963) 52-63 and finally by Charles Isbell, Corpus of the Aramaic Incantation Bowls (Missoula, 1975) 131-2 (Text 58).

${ }^{17}$ Cyrus Gordon, "Aramaic incantation bowls", Orientalia $10(1941) 348$.

${ }^{18}$ BM91713, BM ${ }^{\mathrm{R}}$ 91721, BM 91758 and BM 117883.

${ }^{19}$ Geller, op. cit., 104 acknowledged Naveh and Shaked's collation, to which he added the Pearson bowl, but made no changes to the schema.

${ }^{20}$ Naveh and Shaked, op. cit., 137. 
TABLE 1: Concordance of classification of sections of Refrain A

\begin{tabular}{lll}
\hline Naveh and Shaked & \multicolumn{1}{c}{ Segal } & \multicolumn{1}{c}{ Hunter } \\
\hline (a) & I(a), (b), (c) & I(a), (b), (c), (d) \\
(b) & II & II(a), (b), (c), (d) \\
(c) & III & III $,(b),(c),(d)$ \\
& IV & IV(a), (b), (d) \\
\hline
\end{tabular}

Applying this schema, Naveh and Shaked made the first comparative observation about Refrain A when they noted that parts (a), (b) and (c) were present in $\mathrm{BM}^{\mathrm{R}} 91727$ and BM 91745, but only parts (a) and (b) occurred in $\mathrm{BM}^{\mathrm{R}}$ 91720, the Safani bowl and IM 9726. ${ }^{21}$

Segal revised this schema in his collation of eleven incantation texts belonging to Refrain A, and divided the genre into five sections (I-V). ${ }^{22}$ Naveh and Shaked's sections (b) and (c) were left unaltered to become Segal II and III respectively but he subdivided Naveh and Shaked (a) into three parts:

I(a) the verbal action conjugated from $\sqrt{ }$ HPK applied to

I(b) astrological phenomena, and

I(c) the curses of relatives (female) and other people.

Segal also expanded the schema of Refrain A to include several new formulae, most notably Section IV: "I heard the voice of the earth" and the reference to the angel NKYR, as well as Section V: "I heard the voice of the nightingale at night, the voice of the cock at daybreak". Naveh and Shaked may have excluded Section V from their schema on the grounds that it was not found in AMB B2, but they have made no comment over the omission of Section IV which, as we will see, is a cardinal element of Refrain A.

Segal's classification has, in turn, provided the basis for the amended schema of Refrain A that is now offered by Hunter. These are:

- Section I, the series of participles which Segal included within (c) is considered to be separate and is designated as $I(d)$.

- Section II has been subdivided into II(a)-(c)

- Section IV has been subdivided into IV(a)-(d).

- Section $\mathrm{V}$ is excluded since it is considered to be a later appendage to the original text of Refrain A.

\section{Textual Explorations in Refrain A}

The following discussion of the selection and sequence of the formulae in the dozen exemplars of Refrain $\mathrm{A}$ is based on published transliterations and translations of the texts. ${ }^{23}$ An overview of the sequence of sections and formulae as they appear in the different exemplars is given in Table 2.

\section{Preludes to Refrain A}

Refrain A commences with Formulae I(a) and I(b), which are introduced by preludes in many of the incantation bowls. These range from a single word lyt "accursed" in BM 91713 and AMB B2 to the common opening formula: 'swt' myn šmy" + client's name "health from heaven for ..." in BM 91758. Longer preludes occur in the Safani bowl and in $B^{R} 91720, B^{R} 91721$ and $B^{R}{ }^{R}$ 91727. The Rawlinson group commences with a general curse protecting Mahperoz son of Hindo from various demons, especially dyptkry ... 'idol spirits". In BM ${ }^{\mathrm{R}} 91720$ mryyh rz' dptkry dypkwn mn bytyh wyhpkwn'l dmpyrwz br hynw "Lord YY. Mystery of the idol spirits that will go forth from the house - and will overturn against - of Mahperoz son of Hindo" is also written within the circle drawn in the interior of the bowl. $\mathrm{BM}^{\mathrm{R}} 91721$ has skilfully pre-empted the opening

\footnotetext{
${ }^{21}$ Naveh and Shaked, loc. cit.

${ }^{22}$ Segal, op. cit., 153-5. He did not include IM 9726 in his collation of Refrain A, since the complete text was not at his disposal.

${ }^{23}$ For the British Museum's incantation bowls consult
}

Segal, op. cit., 43-54; for AMB B2 see Naveh and Shaked, op. cit. (n. 11); for the Pearson bowl and IM 9726 see Geller, op. cit. (n. 12) and Hunter, op. cit. (n. 10); for the Safani bowl see Yamauchi, op. cit. (n. 13). 
TABLE 2: Synchronic chart of selection and sequence of formulae in Refrain A

Key: ? = lacuna in text or incomplete formula; [] = secondary element, included in Segal's schema; A = Amen, Selah formula; $\mathrm{B}+\mathrm{S}=$ binding and sealing formulae; $\mathrm{P}=$ prelude to incantation

\begin{tabular}{|c|c|c|c|c|c|c|c|c|c|c|c|}
\hline $\begin{array}{c}B M \\
91745\end{array}$ & $\begin{array}{c}B M^{R} \\
91720\end{array}$ & $\begin{array}{c}B M^{R} \\
91716\end{array}$ & $\begin{array}{c}B M^{\mathrm{R}} \\
91727\end{array}$ & $\begin{array}{c}B M \\
91713\end{array}$ & $\begin{array}{c}B M \\
91758\end{array}$ & $\begin{array}{c}A M B \\
B 2\end{array}$ & $\begin{array}{c}I M \\
9726\end{array}$ & $\begin{array}{c}\text { Pearson } \\
\text { bowl }\end{array}$ & $\begin{array}{c}B M^{R} \\
91721\end{array}$ & $\begin{array}{c}\text { Safani } \\
\text { bowl }\end{array}$ & $\begin{array}{c}B M \\
117883\end{array}$ \\
\hline $\mathrm{Ia}$ & $P$ & IVa & $\mathbf{P}$ & $\mathbf{P}$ & $\mathrm{P}$ & $\mathrm{P}$ & Ia & Ia & $P$ & $P$ & Id \\
\hline $\mathrm{Ib}$ & $\mathrm{Ia}$ & $\mathrm{IVb}$ & Ia & Ia & Ia & Ia & $\mathrm{Ib}$ & $\mathrm{Ib}$ & Ia & Ia & $\mathrm{B}+\mathrm{S}$ \\
\hline Ic & $\mathrm{Ib}$ & IVc & $\mathrm{Ib}$ & $\mathrm{Ib}$ & $\mathrm{Ib}$ & Ib & Ic & Ic & $\mathrm{Ib}$ & $\mathrm{Ib}$ & IIa \\
\hline Id & Ic & IVd & Ic & Ic & Ic & Ic & Id & Id & Ic & Ic & $\mathrm{IIb}$ \\
\hline $\mathrm{B}+\mathrm{S}$ & Id & Ib & Id & $B+S$ & $B+S$ & $B+S$ & $B+S$ & $\mathrm{~B}+\mathrm{S}$ & Id? & Id & \\
\hline IIa & $\mathrm{B}+\mathrm{S}$ & Ic & $B+S$ & IIa & IIa & $\mathrm{IIa}$ & IVc & IVc & $B+S$ & IIa? & \\
\hline IIb & IIa & Id & $\mathrm{IIb}$ & IIb & IIb & $\mathrm{IIb}$ & $\mathrm{IIb}$ & IIb & Ila? & $\mathrm{IIb}$ & \\
\hline IIc & $\mathrm{IIb}$ & $\mathrm{B}+\mathrm{S}$ & IIc & IIc & IIc & IIc & [V] & [V] & IIb & IIc? & \\
\hline$B+S$ & IIc & Ia & $B+S$ & $B+S$ & $B+S$ & $\mathbf{B}+\mathbf{S}$ & & & IIc & A & \\
\hline III & III & $\mathrm{Ib}$ & III & III & III & III & & & & $B+S$ & \\
\hline IVa & $B+S$ & Illb & IVa & IVa & IVa & IVa & IVa & & & & \\
\hline IVb & IVa? & IIc & IVb & IVb & IVb & IVb & & & & & \\
\hline IVc & IVb? & $B+S$ & IVc & IVc & IVc & IVc & & & & & \\
\hline IVd & IVc & & IVd & IVd & IVd & IVd & & & & & \\
\hline$[\mathrm{V}]$ & IVd & & & & A & & & & & & \\
\hline & A & & & & & & & & & & \\
\hline
\end{tabular}

command of Refrain A to state that the demons wythpkwn "will be overturned", which $\mathrm{BM}^{\mathrm{R}}$ 91727 has extrapolated as follows: wythkn pkn wyzln ' $l$ 'wbdyn w'l mšd( $r$ ) nyhwn "they shall be (overturned) and go against the practitioners and those who sent them". In doing so, it supplies a rare insight into praxis.

\section{Section I}

Naveh and Shaked identified Section I as 'hpyk' hpyk' ... + a list of (negative) objects to be reversed, especially the curses of relatives and other men and women". ${ }^{24}$ Segal and Hunter have divided Section I into four separate formulae:

I(a) the verbal action conjugated from $\sqrt{ }$ HPK that is applied to

I(b) astrological phenomena and

I(c) the curses of female relatives

I(d) a concatenation of three verbs: $\sqrt{ }$ BRK $+\sqrt{ }$ NPL $+\sqrt{ }$ LWT

Formula I(a). hypykh "overturned". Refrain A commences with multiple expressions of the striking invocation: hypykh "overturned". The Haphel of $\sqrt{\mathrm{APK}} / \sqrt{ } \mathrm{HPK}$ may articulate the action which was to be taken against the evil entities as well as denoting the burial of the incantation bowl "downturned". 25

\section{Selection and sequence}

- Commences Refrain A except in BM 117883, which is only an extract of Refrain A, and BM $^{\mathrm{R}}$ 91716, where Formula I(a) occurs midway in the text [segment III 1.39].

Formula $\mathrm{I}(\mathrm{b})$. ' $r$ " ... šmyh ... kwkby ... mzly... šth $d k l$ bny' ' $y n s ̌ h$ "earth ... heavens ... stars ... planets ... hour of all mankind". This concatenation of heavenly sections highlighting the astrological orientation of Refrain A is always combined with the invocation $h p y k^{\prime}{ }^{26}$ For a diagnostic chart of Formulae I(b) and (c) in Refrain A see Table 3.

\footnotetext{
${ }^{24}$ Naveh and Shaked, op. cit., 137.

${ }^{25}$ Cyrus H. Gordon, "The Aramaic incantation bowls in historic perspective" in M. Fishbane and M. Brettler, Minhah le Nahum. Biblical and other Studies Presented to Nahum B. Sarna in Honour of his 70th Birthday (Sheffield, c1993) 142. See Erica C. D. Hunter, "Saints in Syriac
}

anathemas: a form-critical analysis of role", Journal of Semitic Studies, 37: 1 (1987) 83-104 for discussion of formcritical elements in amulets.

${ }^{26}$ hpyk' $k l$ myly "upset all the words" in Yamauchi, op. cit., 515 might be read as "planets". Naveh and Shaked, op. cit., 138 also suggest this reading. 
TABLE 3: Refrain A Formulae I(b)-I(c): Elements to be overturned

\begin{tabular}{|c|c|c|c|c|c|c|c|c|c|c|}
\hline & & & & & Key & & & & & \\
\hline $\begin{array}{l}\text { Formul } \\
1=\text { ear } \\
2=\text { hea } \\
3=\text { sta } \\
4=\text { pla } \\
5=\text { ma } \\
6=(\text { ho } \\
11=\text { al } \\
12=\check{s y} \\
\text { Formul } \\
7=\text { cur }\end{array}$ & $\begin{array}{l}1(b) \\
\text { ens } \\
\text { ts } \\
\text { ets and } \\
\text { r/curse) } \\
\text { vords } \\
\text { demon } \\
I(c)\end{array}$ & mankind & & $\begin{array}{l}7 \mathrm{a}= \\
7 \mathrm{ai}= \\
7 \mathrm{~b}= \\
7 \mathrm{c}= \\
7 \mathrm{~d}= \\
7 \mathrm{e}= \\
7 \mathrm{e}(\mathrm{b} \\
7 \mathrm{f}= \\
7 \mathrm{fi}= \\
7 \mathrm{fii}= \\
7 \mathrm{fiii}\end{array}$ & $\begin{array}{l}f \text { the m } \\
\text { of the fa } \\
\text { f the da } \\
\text { f the da } \\
\text { f the m } \\
\text { ien and } \\
=\text { mank } \\
\text { anding } \\
\text { the fie } \\
\text { n the to } \\
\text { on the }\end{array}$ & $\begin{array}{l}\text { er } \\
\text { er } \\
\text { hter } \\
\text { hter-in-l } \\
\text { ler-in-la } \\
\text { men } \\
\text { untain }\end{array}$ & & & $\begin{array}{l}\text { in the te } \\
\text { in the syl } \\
\text { on the } \mathrm{s} \\
=\text { in the } \mathrm{p} \\
=\text { at the } \\
\text { at the th } \\
\mathrm{r} \text { and nea } \\
\text { ar } \\
\text { near } \\
\text { rceries }\end{array}$ & $\begin{array}{l}\text { ple } \\
\text { gogue } \\
\text { re } \\
\text { ce } \\
\text { te } \\
\text { shold } \\
\end{array}$ \\
\hline $\begin{array}{c}B M \\
91713\end{array}$ & $\begin{array}{c}B M \\
91758\end{array}$ & $\begin{array}{c}B M \\
91745\end{array}$ & $\begin{array}{c}B M^{R} \\
91716\end{array}$ & $\begin{array}{c}B M^{R} \\
91720\end{array}$ & $\begin{array}{c}B M^{R} \\
91721\end{array}$ & $\begin{array}{c}B M^{R} \\
91727\end{array}$ & $\begin{array}{c}A M B \\
B 2\end{array}$ & $\begin{array}{c}\text { Safani } \\
\text { bowl }\end{array}$ & $\begin{array}{c}\text { Pearson } \\
\text { bowl }\end{array}$ & $\begin{array}{c}I M \\
9726\end{array}$ \\
\hline 1 & 1 & 2 & $7 \mathrm{e}(\mathrm{b})$ & 1 & 1 & 2 & 1 & 1 & 1 & 1 \\
\hline 2 & 2 & 1 & $7 \mathrm{a}$ & 2 & 2 & 3 & 2 & 2 & 12 & 12 \\
\hline 3 & 3 & 3 & $7 b$ & 3 & 3 & 4 & 3 & 11 & 6 & 6 \\
\hline 4 & 4 & 4 & $7 \mathrm{c}$ & 4 & 4 & 6 & 4 & $7 \mathrm{a}$ & $7 \mathrm{a}$ & $7 a$ \\
\hline 5 & 5 & 7 & $7 d$ & 6 & 6 & 9 & 6 & $7 b$ & $7 \mathrm{~b}$ & $7 b$ \\
\hline 6 & 6 & 6 & 8 & $7 a$ & $7\{a\}$ & $7 \mathrm{ai}$ & $7 a$ & $7 \mathrm{c}$ & $7 \mathrm{c}$ & $7 c$ \\
\hline $7 a$ & $7 a$ & $7 a$ & $7 \mathrm{fi}$ & $7 \mathrm{~b}$ & $7\{b\}$ & $7 a$ & $7 b$ & $7 \mathrm{~d}$ & $7 \mathrm{~d}$ & $7 \mathrm{~d}$ \\
\hline $7 b$ & $7 b$ & $7 b$ & $7 \mathrm{fii}$ & $7 \mathrm{c}$ & $7 \mathrm{c}$ & $7 \mathrm{~b}$ & $7 \mathrm{c}$ & 8 & 8 & 8 \\
\hline $7 \mathrm{c}$ & $7 \mathrm{c}$ & $7 d$ & 1 & $7 \mathrm{~d}$ & $7\{d\}$ & $7 \mathrm{c}$ & $7 d$ & $7 \mathrm{fi}$ & $7 \mathrm{fi}$ & $7 \mathrm{fi}$ \\
\hline $7 \mathrm{~d}$ & $7 d$ & $7 \mathrm{c}$ & 2 & $7 \mathrm{fi}$ & 8 & $7 d$ & $7+7 e$ & $7 f i i$ & 7 fii & 7 fii \\
\hline $7 e$ & $7 \mathrm{e}(\mathrm{b})$ & 8 & 4 & $7 \mathrm{fii}$ & $7 \mathrm{fi}$ & 10 & $7 \mathrm{fi}$ & 7 fvi & $7 \mathrm{fi}$ & $7 f_{i}$ \\
\hline $7 \mathrm{fi}$ & $7 \mathrm{fi}$ & $7 f+8 a$ & & $7 \mathrm{fi}$ & 7 fii & 8 & 7 fii & & $7 \mathrm{fi}$ & \\
\hline $7 \mathrm{fii}$ & $7 \mathrm{fii}$ & $7 f+8 b$ & & & & $7 \mathrm{fi}$ & 7 fiii & & 7 fvii & \\
\hline 7fiii & 7 fiii & & & & & 7 fii & 7 fiv & & 7 fviii & \\
\hline $7 \mathrm{fiv}$ & $7 \mathrm{fiv}$ & & & & & $7 \mathrm{fi}$ & $7 \mathrm{fv}$ & & $7 \mathrm{fix}$ & \\
\hline $7 \mathrm{fv}$ & $7 \mathrm{fv}$ & & & & & 10 & & & & \\
\hline
\end{tabular}

\section{Selection and sequence}

- Present in all incantation texts, except BM 117883.

- Always coupled with Formula I(a).

- BM $^{\mathrm{R}} 91716$ Formula I(b) [segment III (11. 40-3?)] follows Formula I(a). An earlier excerpt of Formula I(b) might be suggested by the phrase $d k l$ bny' 'ynšh "hour of all mankind" [section II (1. 17)] but the preceding text [section I (11. 15-16)] has deteriorated.

\section{Textual variants}

- $\mathrm{BM}^{\mathrm{R}} 91727$ omits ' $r$ " "earth" and substitutes $h\langle>$ šryh "sorceries".

- IM 9726 and the Pearson bowl suspend Formula I(b) after ' $r$ " "earth" by replacing the concatenation šmyh ... kwkby ... mzly "heavens ... stars ... planets" with šyq' "goblin". ${ }^{27}$

- BM 91713 and BM 91758 have coupled šwqy "markets" with wbyryt" "streets" and interpolated the phrase into the original sequence, to read: hpykh ' $r$ " wšmyh ... kwkby wmzly ... šwqy wbyryt' ... s't' dkwl bny' 'ynš (11. 1-3) 'overturned be the earth and the heavens, ... the stars and the planets, ... the streets and the markets, ... the hour of all human kind".

- IM 9726 and the Pearson bowl substitute $l w t t$ " "curse" for $\check{s} t$ " "hour" to produce $l w t t$ ' dkl bny 'ynšh "the curse of all mankind". ${ }^{28}$

\footnotetext{
${ }^{27}$ Segal, op. cit., 43 notes that this was a misreading of šwq "markets". Naveh and Shaked, loc. cit., suggest that syq" "goblin" is a corruption smy' "heavens", presumably on the basis of the expected sequence of Formula I(b). Geller, op. cit., 104 makes no comment other than noting the occurrence of this word in Montgomery (who translates it as "goblin") and stating that $\check{s} y q$ ' and $s^{y} y d^{\prime}$ are synonymous terms for "demon".
}

${ }^{28}$ Naveh and Shaked, loc. cit., justify their reading of $\breve{s}^{\prime} t$ "hour" in AMB B2 as "talk", but miss the point that Formula I(b) is a concatenation of astrological phenomena, in which "fate of all mankind" is entirely fitting. BM 91716 prefaces Formula I(a) + I(c) with a phrase (11. 17-19) dkl bny \{'ynš\} 'ynš "of all humankind" but there is a lacuna in the text beforehand. 
Formula I(c). dym' wybrt' dklt' wyhtym' "mother, daughter, mother-in-law and daughter-in-law". The curses of this listing of female relatives are the overriding concern of Refrain A. Formula I(c) is a core element of Refrain A, and may owe its origins to the Assyrian Maqlûu series. ${ }^{29}$

\section{Selection and sequence}

- Present in all incantation bowls, except BM 117883.

- Always combined with Formula I(d).

- $\mathrm{BM}^{\mathrm{R}} 91716$ has moved Formula I(c) [segment II.19-23] out of sequence to follow Formula IV(d) [segment I.10-15].

\section{Textual variants}

- BM 91745, Safani, Pearson and IM 9726 d'ymh. $^{30}$

- $\mathrm{BM}^{\mathrm{R}} 91727$ interpolates $d$ ' $b$ ' "of the father" at the beginning of Formula I(c). This interpolation has no counterpart in any other text.

- $\quad B M 91745, B^{\mathrm{R}}$ 91716, $\mathrm{BM}^{\mathrm{R}}$ 91721, $\mathrm{BM}^{\mathrm{R}}$ 91727, the Safani and Pearson bowls and IM 9726 qualify the listing of female relatives by the adjectives rhyqt' wdybrt' "far and near".

- BM 91758 and BM 91713 introduce a masculine element by replacing rhyqt' wdybrt' "far and near" with the generic term wdybr "ynšy "mankind". This may be the source of AMB B2 dgbry wynsy "men and women".

- BM 91758, BM 91713 and AMB B2 all have written $3 \mathrm{~m}$. pl. participial $\sqrt{\text { QWM }}$ in the following clause, which states that the cursers qwmyn bdbr' wybmt' "are standing in the field and in the town".31

$b d b r^{\prime}$ 'wybmt' "in the field and in the town", i.e. the location where the female relatives stood and cursed, has various permutations:

- $\mathrm{BM}^{\mathrm{R}}$ 91720, $\mathrm{BM}^{\mathrm{R}}$ 91727, IM 9726 and the Pearson bowl repeat $b d b r$ " "in the open field", to read "in the open field ... in the village ... in the open field", with the Pearson bowl reiterating $b d b r$ ' "in the open field".

- BM 91745 makes no mention of location, but qualifies dqym' "standing" with brwhq' "near" and $b q w r b$ " "far".

- BM 91713, BM 91758 and AMB B2 omit Formula I(d) but add to the listing: wybtwr' wbyt 'ylhy wbyt knyšt' "on the mountain, and (in) the temple and the synagogue".

Formula $\mathrm{I}(\mathrm{d})$. This series of actions, distinguished by a concatenation of three verbs $\sqrt{\mathrm{BRK}}+\sqrt{\mathrm{NPL}}+\sqrt{\mathrm{LWT}}$, relates to the aforementioned cursers (see Table 4 ).

TABLE 4: Refrain A Formula I(d)

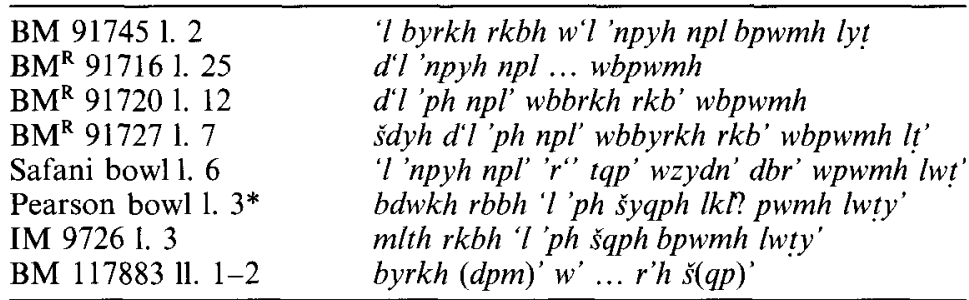

* For corrections to the reading offered by Geller, see Hunter, Iraq 62 (2000) 142.

\footnotetext{
${ }^{29}$ Yamauchi, op. cit., 51 mentions the Maqlû series, referring to K. L. Tallqvist, Die assyrische Beschwörungen Maqlû (Leipzig, 1895) 17.

${ }^{30}$ Naveh and Shaked, op. cit., 137 note the elision of an initial alef following a prefixed element. See Hannu Jusoola, Linguistic Peculiarities in the Aramaic Magic Bowl Texts (Helsinki, 1999) 34 for further examples of the omission of alef in $\mathrm{AMB} \mathrm{B} 2$.
}

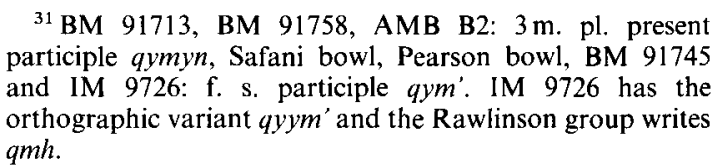

${ }^{31}$ BM 91713, BM 91758, AMB B2: $3 \mathrm{~m}$. pl, present and IM 9726: f. s, participle gym' IM 9726 has the orthographic variant qyym' and the Rawlinson group writes 


\section{Selection and sequence}

- Present in all bowls except BM 91713, BM 91758 and AMB B2.

- $\mathrm{BM}^{\mathrm{R}} 91721$ has a textual lacuna at this point.

- BM $^{\mathrm{R}} 91716$ Formula I(d) [segment II.24-6? (textual deterioration at this point)].

Textual variants.

- $\mathrm{BM}^{\mathrm{R}}$ 91716, $\mathrm{BM}^{\mathrm{R}} 91720$ and $\mathrm{BM}^{\mathrm{R}} 91727$ have modified the order to $3 \mathrm{f}$. s. participles $\sqrt{ } \mathrm{NPL}+\sqrt{ } \mathrm{BRK}+\sqrt{ } \mathbf{L W T}$

- IM 9726, the Pearson bowl and BM 117883 have substituted šyqph "struck" for $3 \mathrm{f}$. s. participle $n p l$ " "falling". 32

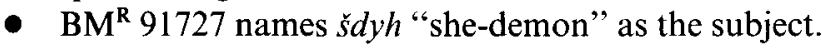

- The Safani bowl has interpolated the earth as the subject of 'l 'ph $n p l$ ' 'r" $t q p$ ' $w z y d n$ '? $d b r^{\prime}$ $w p w m$ ' lwt' "the powerful earth fell upon its nose; and the raging word and cursing mouth", $(11.6-7) .^{33}$

- BM 91745 links ' lbyrkh rkbh w'l'nph npl bpwmyh lyt "upon his knees kneeling, and upon his face falling, with his mouth cursing" with the adversary, Mešaršiyah son of Porti.

\section{Transition from Section I to Section II}

Statements of "binding and sealing" that are typical of incantation texts bridge Sections I and II in all incantation bowls, with the possible exception of $\mathrm{BM}^{\mathrm{R}}$ 91721, where the text has deteriorated.

- BM 91713, BM 91758, BM 117883, AMB B2 and the Safani bowl employ varying combinations of $\sqrt{ }$ 'SR and $\sqrt{\text { HTM }}$ to bind and seal lwtt' dltt "the curse that she cursed". The female subject is undisclosed.

- BM 91745 directs the binding and sealing of Mešaršiyah son of Porti as the perpetrator of the curse.

- $\mathrm{BM}^{\mathrm{R}} 91716, \mathrm{BM}^{\mathrm{R}} 91720$ and $\mathrm{BM}^{\mathrm{R}} 91727$ stipulate that the curses are to be directed away from the client and in doing so reiterate the thrust of the preludes to the texts.

- IM 9726 and the Pearson bowl partially reiterate the opening clause, 'wpykh lwtt'... wdmndyr $w l w t w . s d r$ ' "overturned is the curse ... which is vowed and cursed and sent against" their client, 'HBTY daughter of MHLPT' $m n$ spnh wym' $m n$ twr $m y d n h$ "from the north of the day, from the mountain of the east". Cf. BM ${ }^{\mathrm{R}} 91716$ wd't' dlyty' wšdr' lt msypwn' wmm'rb' wltwr $m d n h h$ "and of a woman(?) who curses and sends [a curse] from the north and from the west and to the mountain of the east" [section I: 11. 10-12] which follows Formula IV(d).

\section{Section II}

Naveh and Shaked described this as an "invocation of angels, especially a group of eleven names which constitute the person of yyy the Great". ${ }^{34}$ Hunter has subdivided Segal's Section II into:

(a) invocation in the name of byty'l wyqwty'l "Betiel and Yequtiel".

(b) a second invocation byšmyh dyyy rb' ml'kh dytlyh hd'šr šmyn "in the name of YY the Great, the angel" + a listing of the eleven names. ${ }^{35}$

(c) a warning against transgressing against the names.

Formula II(a). Invocation in the name of byty'l wyqwty'l "Betiel and Yequtiel"

\section{Selection and sequence}

- Present in all bowls except $\mathrm{BM}^{\mathrm{R}}$ 91727, IM 9726 and the Pearson bowl.

- $\mathrm{BM}^{\mathrm{R}} 91716$ [segment III.43?], $\mathrm{BM}^{\mathrm{R}} 91721$ [1. 9?] have textual lacunae.

- IM 9726 and the Pearson bowl have replaced wbšwm byty'l wyqwty'l "in the name of Betiel and Yequtiel" with Formula IV(c), which has been moved out of sequence.

\footnotetext{
${ }^{32}$ Segal, op. cit., 45 has read this word as "lintel"

${ }^{33}$ Yamauchi, op. cit., 514-15. Cf. BM ${ }^{R} 917271.7: w^{\prime} r$ " 'tqwpt(h lyšr' ... "and the earth is powerful ..."

${ }^{34}$ Naveh and Shaked, op. cit., 137.
}

\footnotetext{
${ }^{35}$ Segal, op. cit., 43 comments that this name is a variant of the familiar Bethel and pointing out that Yequtiel is cited in I Chronicles IV.18.
} 
TABLE 5: Names of YY "the great, the angel"

\begin{tabular}{|c|c|c|c|c|c|c|c|c|c|c|}
\hline $\begin{array}{c}B M \\
91713\end{array}$ & $\begin{array}{c}B M \\
91758\end{array}$ & $\begin{array}{c}B M \\
117883\end{array}$ & $\begin{array}{c}B M \\
91745\end{array}$ & $\begin{array}{c}B M^{R} \\
91716\end{array}$ & $\begin{array}{c}B M^{R} \\
91720\end{array}$ & $\begin{array}{c}B M^{R} \\
91727\end{array}$ & $\begin{array}{c}A M B \\
B 2\end{array}$ & $\begin{array}{c}\text { Safani } \\
\text { bowl }\end{array}$ & $\begin{array}{c}\text { Pearson } \\
\text { bowl }\end{array}$ & $\begin{array}{c}I M \\
9726\end{array}$ \\
\hline $\begin{array}{l}s s k b ' \\
k k b^{\prime} \\
k n y b r^{\prime} \\
\text { syr' } \\
\text { syr'dy' } \\
\text { mryry' } \\
\text { 'nny' } \\
\text { btwqp' } \\
\text { 'nqp' } \\
\text { 'ns psps } \\
\text { kybyby } \\
\text { bnwr' }\end{array}$ & $\begin{array}{l}s s k b ' \\
k b b ' \\
k n b r^{\prime} \\
s y r^{\prime} \\
\text { sy'ry' } \\
\text { mryry' } \\
\text { 'nny' } \\
\text { btwqp' } \\
\text { 'nqp' } \\
\text { 'nsps psps } \\
\text { kbyby } \\
\text { bnwr' }\end{array}$ & $\begin{array}{l}k k b^{\prime} \\
k(n) b r^{\prime} \\
s\left(r y d y^{\prime}\right)\end{array}$ & $\begin{array}{l}\text { sskb' } \\
\text { srtyh } \\
\text { kbk' } \\
\text { dmyryr } \\
\text { 'nyny } \\
\text { (btwqp) } \\
\text { btwqp' } \\
\text { nttnt } \\
\text { pkrps } \\
\text { kbybn } \\
\text { bnwr' }\end{array}$ & $\begin{array}{l}s s \\
k r b ' \\
\ldots . b \\
\text { sydryh } \\
h y d r y h \\
\ldots . y h \\
\text { btqp' } \\
\text { 'wqp' } \\
\text { 'nsps } \\
\text { kbyby } \\
\text { bnwry' }\end{array}$ & $\begin{array}{l}\text { sskbh } \\
\text { sryh } \\
k k b \text { ' } \\
k b y b \text { ' } \\
\text { swdryh } \\
\text { 'wznyh } \\
\text { btqpt' } \\
n w q p \text { ' } \\
\text { 'nsps } \\
\text { kbyby } \\
\text { bnwr' }\end{array}$ & $\begin{array}{l}s s k b \text { ' } \\
s r y h \\
k b b \text { ' } \\
k r b k ' \\
\text { sydryh } \\
\text { hydryh } \\
\text { 'znyh } \\
\text { btwqp' } \\
\text { 'wqp' } \\
\text { 'nsps } \\
\text { kbyby } \\
\text { 'bnwry }\end{array}$ & $\begin{array}{l}s s k b b^{\prime} \\
k k b^{\prime} \\
k n b r^{\prime} \\
s d y^{\prime} \\
s w d ' r y^{\prime} \\
m r y r y ' \\
\text { 'nqp' } \\
\text { 'ns } \\
p s p s \\
k b y b y \\
\text { bnwr' }\end{array}$ & $\begin{array}{l}s s b^{\prime} \\
k r b^{\prime} \\
k b k^{\prime} \\
m r w h \\
\text { sw? } \\
h^{\prime} p n y^{\prime} \\
\dot{k} t y p^{\prime} \\
\text { hlm } \\
\text { ssspb } \\
\text { blwr' }\end{array}$ & $\begin{array}{l}\text { spskh } \\
\text { spskh } \\
\text { spysbh } \\
\text { sryh } \\
\text { yznyh } \\
\text { sryh } \\
\text { pgpgpg } \\
\text { brbr } \\
k k r \\
k y b y b y \\
\text { bnyr' } \\
\text { bnyr' }\end{array}$ & $\begin{array}{l}\text { spskh } \\
\text { spskh } \\
\text { spskh } \\
\text { sryh } \\
\text { sryh } \\
\text { sryh } \\
\text { pgpgpg } \\
\text { brbr } \\
k k r \\
k y b y b y \\
\text { bnwr' }\end{array}$ \\
\hline
\end{tabular}

N.B. BM 91721 commences with $s s k b^{\prime}$ but the text has deteriorated at this point.

\section{Textual variants}

- BM 91745 by'ty'l "Beatiel".

- Safani bowl tšhy'l wyqty'l "Ṭashniel (sic) and Yaqtiel". ${ }^{36}$

Formula II(b). dyyy rb' ml'kh dytlyh ḩd 'šr šmyn "YYY the great, the angel who has eleven names".

\section{Selection and sequence}

- Present in all bowls except $\mathrm{BM}^{\mathrm{R}} 91716$ [segment III.43?], $\mathrm{BM}^{\mathrm{R}} 91721$ [1. 9?], where there is textual deterioration and the epithet of the great angel is not cited.

\section{Textual variants}

The epithet of the great angel has undergone considerable corruption to produce no less than five forms:
(i) $y y y$
BM 91713, AMB B2.

(ii) $y h$

(iii) $y y b r h \quad$ IM 9726 and the Pearson bowl; ${ }^{37} b r h$ is a metathesis of $r b$ '.

(iv) $y w r b b^{\prime}$ BM 117883, the Safani bowl; ${ }^{38} y w r b^{\prime}$ has been interpreted as the Mandaean deity linked with the sun, Yorba. ${ }^{39}$ It is a contracted misinterpretation of the original epithet yyy qualified by $r b h^{40}$

(v) $y t b^{\prime} \quad \mathrm{BM} 91745, \mathrm{BM}^{\mathrm{R}} 91720, \mathrm{BM}^{\mathrm{R}} 91727 ; y t b^{\prime}$ derives from $y w r b^{\prime}$ Yorba to become, in a process of continuing palaeographic deterioration, $y t b^{\prime}$ Yatba, as Segal has noted. ${ }^{41}$

All incantation bowls state unanimously that YY had eleven names. ${ }^{42}$ However, the numbers of names that are actually written vary (see Table 5). ${ }^{43} \mathrm{BM}^{\mathrm{R}} 91716$ and $\mathrm{BM}^{\mathrm{R}} 91720$ list nine, $\mathrm{BM}^{\mathrm{R}}$ 91727 has ten. This disparity demonstrates the flexibility of the transmission process, which Naveh and Shaked have described as "something like a free adaptation", and also illustrates that textual rigour was not a prerequisite for an efficacious incantation. ${ }^{44}$

Differences do arise between the listings of names in the incantation bowls, but less often than might be expected, indicating the fairly intact transmission of this section. ${ }^{45}$ Orthographic corruption has rendered most of the names in garbled form, but occasionally some sense can be

\footnotetext{
${ }^{36}$ Yamauchi, op. cit., 519 suggests that the name of the angel Tashniel is related to the root " 20 "to hide, protect". Naveh and Shaked, op. cit., 139 read $\check{s} d y h y ' l$. 144.

${ }^{37}$ For corrections to Geller's reading see Hunter, op. cit.,

${ }^{38}$ Naveh and Shaked, op. cit., 140 suggest the latter text be corrected to $y y r b h$.

${ }^{39}$ See Yamauchi, loc. cit., for Yorba in Mandaean literature.

${ }^{40}$ Naveh and Shaked, op. cit., $139-40$.

${ }^{41} \mathrm{Cr}$. Segal, op. cit., 45.
}

${ }^{42}$ Lists of multiple names are common in amulets and incantations. Cf. Syriac anathema of Mar 'Abdisho where the demoness has twelve names. See Erica C. D. Hunter, "Saints in Syriac anathemas: a form-critical analysis of role", Journal of Semitic Studies, 37: 1 (1987) 83-104.

${ }^{43}$ Note the oscillation between Semkath and Sin/Shin in hd ' $s r$.

${ }^{44}$ Naveh and Shaked, op. cit, 140.

${ }^{45}$ See Naveh and Shaked, op. cit., 141 for a tabulation of names in the collated texts. 
salvaged. Segal suggests that the final two names, kbyby and $b n w r$ ', be read as "scorched by fire". ${ }^{46}$ These two names conclude the otherwise independent listing of IM 9726 and the Pearson bowl.

Formula II(c). kwl mn d'br 'l hlyn šmht "whoever transgresses against those names".

\section{Selection and sequence}

- Present in all incantation bowls except BM 117883, also IM 9726 and the Pearson bowl, which list evil spirits and reiterate the main theme of the incantation, i.e. the overturning of curses, with their texts tailored to match the gender of the clients for whom they were written. ${ }^{47}$

- The Safani bowl has a textual lacuna.

\section{Textual variants}

- BM 91713, BM 91758, BM ${ }^{\mathrm{R}}$ 91720, AMB B2 qualify this warning with $m l$ 'ky ' $y l y n$ "these angels".

- BM 91745 prefers dl' mtqryn dwkhwn dhlyn šmht' hw' nwsrh (wnwsțtmyh) wnwsttmyh lmšr šy' br $\{p w m\}$ pwrty "the places of these names are not proclaimed - he will bind him and will stop him up, namely Mešaršiyah son of Porti".

The texts continue with statements of binding and sealing evil spirits, without spelling out what would happen should a transgression occur. ${ }^{48}$ As might be expected, many differences occur in the listings of evil spirits. The statements of binding and sealing have been included as the closing part of Section II but may, in fact, introduce Section III.

\section{Section III}

$w k w l$ dlr" $q r y$ ' wkwl dlysmy' msyt' "All that is of the earth calls, and all that is of the heaven obeys". ${ }^{49}$ Naveh and Shaked isolated this as the statement asserting the efficacy of the invocation. ${ }^{50}$ It appears as III in Segal and Hunter.

- Present in all incantation bowls except BM 117883, IM 9726 and the Pearson and Safani bowls.

- $\mathrm{BM}^{\mathrm{R}} 91716$ and $\mathrm{BM}^{\mathrm{R}} 91721$ have textual lacunae.

\section{Section IV}

Naveh and Shaked did not include in their schema of Refrain A this section, which commences with šm 'yt ql ' $r$ " dqyqyh šmyh "I heard the voice of the earth, DQYQYH is its name". Using Segal's designation of this as Section IV, Hunter has divided it into the following formulae:

(a) hearing the voice of the earth;

(b) hearing the voice of the woman who cursed;

(c) sending of angels NKYR and YY;

(d) rejoicing that the women may not avenge or curse.

Formula IV(a). smm'yt ql 'r' dqyqyh šmyh mqbl' kwl nyšmt' myn hdyn 'lm' "I heard the voice of the earth, DQYQYH is its name, receiving all souls from this world" (see Table 6).

\section{Selection and sequence}

- Present in BM 91713, BM 91758, BM 91745, BM 91716 and AMB B2.

- $\mathbf{B M}^{\mathrm{R}} 917201.17$ has a textual lacuna.

- Absent from BM 117883, BMR 91721, BMR 91727, the Safani bowl, IM 9726 and the Pearson bowl.

- $\mathrm{BM}^{\mathrm{R}} 91716$ commences with a modified formula [segment I 1. 1].

\footnotetext{
${ }^{46}$ Segal, op. cit., 43 where he also suggests that psps is the alphabetic reversal for whwh, a by-form of the ineffable Name.

${ }^{47}$ IM 9726, written for 'HBTY daughter of MḤLPT', states: 'wpykh lwtt' d'ym' wbt'ym' $w$ 'overturned is the curse of the mother and the daughter". The Pearson bowl, written for Yezid Gusnas, offers the interesting variant: wpykh lwtt' dhnyn 'ynšh dyndr wlwt wšdr "overturned is the curse of these men which is vowed, cursed and bound".
}

\footnotetext{
${ }^{48}$ See Yamauchi, op. cit., 515 for hlyn $\check{s} m h t^{\prime} d m l^{\prime} k^{\prime} h d y n$ 'bdyn h'lyn šmrt' whty[m]yn kl sydyn wdywyn "(by) all ... these names of this angel, these conjurations (by these) names (are bound). Bound and sealed are all demons and devils ...'

${ }^{49}$ Naveh and Shaked, op. cit., 137.

${ }^{50}$ Ibid.
} 
TABLE 6: Refrain A Formula IV(a)

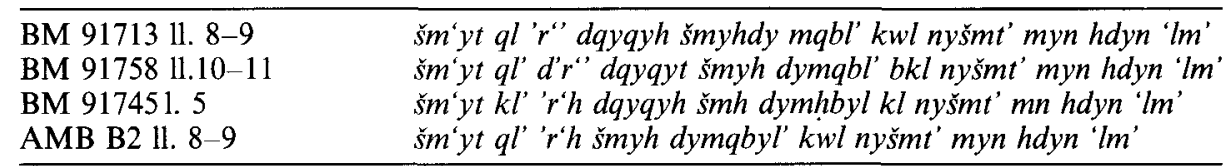

N.B. Minor orthographic variants occur in the earth's name; the substitution of $k l$ for $q l$ in BM 91745 may indicate the phonetic similarity of Qoph and Kaph.

TABLE 7: Refrain A Formula IV(b):

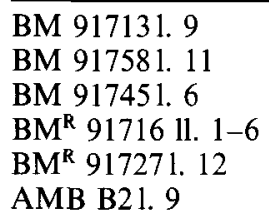

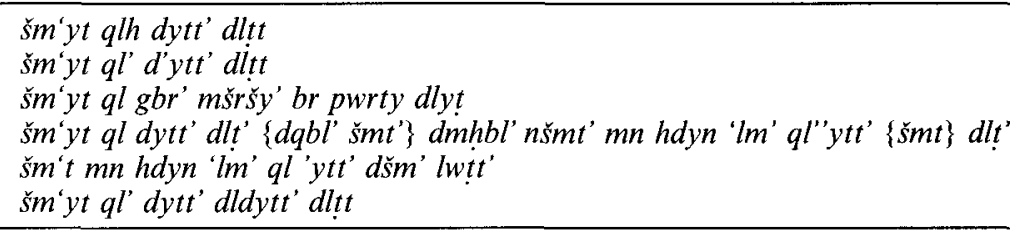

\section{Textual variants}

- AMB B2 omits dqyqyh to present the modified version šm 'yt ql' 'r'h šmyh dymqbyl' kwl nyšmt' myn hdyn ' $I m$ ' "I heard the voice of the earth fleeing and that of the sky receiving all the souls from this world". Naveh and Shaked have suggested that dqyqyh was originally derived from DQH which became corrupted, whilst Segal suggests that it may echo I Kings XIX:12 qōl demāma $\bar{a}$ "the sound of a gentle breeze". ${ }^{1}$ In a concomitant change, smyh "its name" is read as "heaven" to reiterate the combination of heaven and earth.

- $\quad \mathrm{BM}^{\mathrm{R}} 91716$ has modified its contents and substituted $d y t t$ ' dlt' "woman who curses", the subject of Formula IV(b), for ' $r$ " dqyqyh šmyh "earth, DQYQYH is its name", and dmhbl" nšmt' "\{ woman who received souls\} who injures souls" for mqbl' kwl nyšmt" "who received souls".

Formula IV(b). šm 'yt ql dytt' dlt' "I heard the voice of the woman who cursed" (see Table 7). ${ }^{52}$

Selection and sequence

- Present in all incantation bowls except BM 117883, IM 9726 and the Pearson and Safani bowls.

- $\mathrm{BM}^{\mathrm{R}} 91720$ has a textual lacuna.

\section{Textual variants}

- BM 91745 has amended the text substituting $q l$ gbr' mšršy' br pwrty "the voice of the man Mešaršiya son of Porti" for the expected $q l d y t t$ ' dlt ' "the voice of the woman who cursed". This is a dramatic and deliberate move on the part of the copyist, introducing a masculine component into the otherwise specifically feminine dimension of Refrain A that has no parallel in the other incantation bowls.

Formula IV(c). wšdryt 'th ml'kyn "and I sent against her angels", which introduces a sequence of words that all have the initial character Nun.

\section{Selection and sequence}

- Present in all incantation bowls except BM 117883, BM 91721 and the Safani bowl.

- IM 9726 and the Pearson bowl have taken the listing of N-prefix names out of sequence and used them to replace Formula II(a) wbšwm byty'l wyqwty'l "in the name of Betiel and Yequtiel", which introduces the angel with eleven names. ${ }^{53}$

\section{Textual variants}

- BM 91745 has changed the gender of this formula from feminine to masculine so that the angels would be sent against Mešaršiyah son of Porti. ${ }^{54}$

\footnotetext{
${ }^{51}$ Naveh and Shaked, op. cit., 143 suggest that the word was a verb. Cf. Segal, op. cit., 44 .

${ }^{52}$ This phrase is reminiscent of a very popular Mandaic refrain. See Segal, op. cit., 123-8. IM 60494 can be added to his listing of extant examples on p. 124. For text and
}

translation see Erica C. D. Hunter, "Who are the demons?", Studi epigrafici e linguistici 15 (1998) 103-15.

${ }_{53}$ Naveh and Shaked (b) and Segal/Hunter II.

${ }^{54}$ Cf. 1.6 wšdryt 'lhy ml'ky. 
TABLE 8: Synoptic chart of N-names

\begin{tabular}{|c|c|c|c|c|}
\hline Bowl No. & Epithet & $N K Y R$ & $N Q W M$ & $N G Y L$ \\
\hline BM 91713 & ml'kyn & $4 \times n k y r$ & $n q w m$ nyqmt $+y y$ & $n g y l w n g y l+y y$ \\
\hline BM 91758 & $m l ' k y n$ & $3 \times n k y r$ & nqwm nyqmt $+y y$ & $n g y l n w g y l h+y h$ \\
\hline BM 91745 & $m l ' k y$ & $2 \times n k y r$ & ynqm nyqm nyqmh & nglh nglh \\
\hline AMB B2 & ml'kyn & $2 \times n k y r$ & $y y+n q w m$ nyqmt & $y y+n g y l$ wngyl \\
\hline $\mathrm{BM}^{\mathrm{R}} 91716$ & mlkyn & nkyr & nyqmh ynqwm nqm' & wngyl nygl'h \\
\hline $\mathrm{BM}^{\mathrm{R}} 91720$ & mlkyn & $n k r n k y r$ & ynqwm nqm' & wngyl ngl \\
\hline $\mathrm{BM}^{\mathrm{R}} 91727$ & $m l k n$ & $2 \times n k y r$ & ynqwm nqm' & wngyl nygl' \\
\hline Pearson bowl & $b s ̌ w m$ & $2 \times n k y r$ & $n g y l+2 \times n g l$ & $2 \times n q m n q[] n r$ \\
\hline IM 9726 & $b \check{w} w m$ & $3 \times n k y r$ & $3 \times n g y l$ & $2 \times n q m$ nqmyt \\
\hline
\end{tabular}

- IM 9726 and the Pearson bowl have coupled the onomatopeic string: $n k y r n k y r$ nkyr ngyl ngylngyl nqm nqm nqmyt, using the phrase brswm "in the name" instead of the expected noun ml'kyn "angels", with wbšwm dyybrh ml'kh d'yt lh hd'šr šmyn spskh spskh spskh sryh sryh sryh pgpgpg brbr nkr kybyby bnwr' "in the name of yy brh, the angel who has eleven names ..."55 In keeping with these changes, IM 9726 and the Pearson bowl have not cited the sibilant clusters that are present in BM 91713, BM 91758 and AMB B2. These may have been uttered in the praxis directed towards $y t y t t$ ' dltt "the woman who cursed". ${ }^{56}$

Various combinations of $\mathrm{N}$-names demarcate the texts, but on the whole the sequences are relatively uniform (see Table 8).

- $n g y l$ Naveh and Shaked, as well as Segal, have translated $n g y l$ as "let us rejoice", i.e. as 1st common imperfect $\sqrt{\text { GYL}}$, and nqm as "let us take vengeance", again as 1 st common imperfect Pael $\sqrt{\text { QYM. }}{ }^{57}$

- $n k y r$ Naveh and Shaked draw attention to the Islamic figure associated with the post mortem trial of the dead and their punishment, and suggest that the term is a possible antecendent. ${ }^{58}$ Segal moots the idea of the "unknown" with the epithet deriving, as angels' names often do, from a verbal root. ${ }^{59}$ The form of $n g y l$ and $n q m$, "let us rejoice" and "let us take vengeance" respectively, may suggest the appellation $n k y r$ as a passive of $\sqrt{ }{ }_{\mathrm{NKR}}$ "let us be estranged", where the preformative Nun may have assimilated with the initial radical of the verbal root. ${ }^{60}$

Formula IV(d). ytytt' dltt "the woman who cursed", which directs stopping the voice of the woman who curses (see Table 9).

\section{Selection and sequence}

- Present in all incantation bowls except BM 117883, the Safani bowl, IM 9726 and the Pearson bowl.

- $\mathrm{BM}^{\mathrm{R}} 91721$ has a textual lacuna at this point.

- BM $^{\mathrm{R}}$ 91716: sswtymh wd't' dlyty' wšdr' lt "stop up and of a woman(?) who curses and sends [a curse]". This formula is followed by Formula I(c).

\footnotetext{
${ }^{55}$ Geller's transliteration of the Pearson bowl reads nyht rather than wym'. On palaeographic grounds only the final Tau can be read with certainty. The first two letters which Geller has intepreted as a Nun-Yodh combination may equally be read as a Waw-Yodh combination, whilst the third letter could be a Mem. See Geller Plate IV in Orientalia Lovaniensia Periodica. The word can also be discerned in the photograph which appeared as Plate XXVII in Pearson, facing page 83. A problem remains with the final Tau. A similar phrase occurs in $\mathbf{B M}^{\mathrm{R}}$ 917161. 11: msypwn' wmm' $r b^{\prime}$ wltwr manhh "from the north and the west and the mountain of the east".

${ }^{56} \mathrm{BM}$ 91713, BM 91758 yy wss șs tymw; AMB B2 yy kyss sss tymw.

${ }^{57} \mathrm{M}$. Jastrow, A Dictionary of the Targumim, the Talmud Babli and Yerushalmi, and the Midrashic Literature (2 vols.; New York, 1951) $238 \sqrt{ }$ GYL and $1332 \sqrt{ }$ QYM.
}

\footnotetext{
${ }^{58}$ Naveh and Shaked, op. cit., 144 note that the appellation nkyr does not occur in Aramaic, and tentatively suggest a reference to the figure who became identified in Islam as the Angel of Death. A. J. Wensinck, "Munkar wa-nakir", Encyclopedia of Islam VII, 577 notes the similarity between Muslim sources with the idea of Hibbut ha-Kever (lit. the beating of the grave) that was well known in Jewish circles during late Antiquity. In the Babylonian Talmud (Berakhot 18b) Duma is named as the angel who punished the deceased after their burial by striking them with fiery chains.

${ }^{59}$ Segal, op. cit., 29.

${ }^{60}$ See E. Drower and R. Macuch, A Mandaic Dictionary (Oxford, 1962) 301 entry NKR, NKRA, R. Payne Smith, $A$ Compendious Syriac Dictionary (Oxford, 1902) 340 entry שרt M. Jastrow, op. cit., $911 \sqrt{\text { NKR. }}$
} 
TABLE 9: Refrain A Formula IV(d):

BM 91713 11. 10-11

BM 91758 11. $12-13$

BM 917451. 7

$\mathrm{BM}^{\mathrm{R}} 91716$ 11. 13-16

$\mathrm{BM}^{\mathrm{R}} 91720$ ll. $17-18$

$\mathrm{BM}^{\mathrm{R}} 917271.13$

AMB B21. 9 wšs $w$ w whbylw yth myn 'nnyn dbrd' dl' tyqwm wl' tylwt

wšdrw whbylw yth myn 'nynyn dbrd' dl' tyqwm wl' tylwt 'mn 'mn slh

mšršy br pwrty dlt wšdr lwttyh lhnplw my' wlytwr mdnh' l kstwht 'l rwwh

whmwth 'ynyn $\{d r k$ '\} dylk $d l$ ' tylwt

tyqwm wl' tylwt wks ... tyqwm wl' tylwt wks

wšdr' ... m'rb' dlyt' wšdr ... dl' tyqwm wl' tyl!

'ytt' dlyth wšdr' ltth"

ytytt' dltt wšdrw whbylw yth myn 'nyn dbr(t)' dl' tyqwm wl' tylwt

\section{Textual variants}

- BM 91713, BM 91758 end with the statement that the woman was injured by myn "nnyn "clouds of hail" so that $d l$ ' tyqwm wl' tylwt "she may not avenge or curse".

- AMB B2 is concerned that the woman $d l$ ' tyqwm wl' tylwt "may not avenge or curse", but does not refer to injury through hailstones. ${ }^{61}$

- BM 91745 has amended this formula to direct that Mešaršiyah son of Porti might be stopped, presumably from cursing.

- $\mathrm{BM}^{\mathrm{R}}$ 91720: sswtymh wd't' dlyty' wšdr' ...; $\mathrm{BM}^{\mathrm{R}}$ 91727: (ss...) 'ytt' dlyṭh wšdr' ltth conclude the incantation texts.

\section{Concluding Refrain $A$}

BM 91713, BM ${ }^{\mathrm{R}} 91727$ and AMB B2 end with Formula IV(d), to which BM 91758 and BM $^{\mathrm{R}}$ 91720 have added combinations of the pious expressions ' $m n$ slh "Amen, Selah" that occur in Aramaic and Mandaic incantation bowls. ${ }^{62}$ In the Safani bowl ' $m n$ ' $m n$ slh "Amen, Amen, Selah" marks the termination of Refrain A after Formula II(c) and is followed by a long series of binding and sealing clauses.

BM 91745, IM 9726 and the Pearson bowl have appended a passage that begins with the distinctive phrase ql bwlbwl blyly ql trngl' bnghy "the voice of the nightingale at night, the voice of the cock at dawn". Segal considered this text to be an integral part of Refrain A and classified it in his schema as [V]. ${ }^{63}$ In a neat piece of dovetailing, the copyist of IM 9726 and the Pearson bowl introduces this formula with 'wpykh lwtt' $d^{\prime} y m^{\prime}$ ' $w b t^{\prime} y m^{\prime} w$ 'overturned is the curse of the mother and the daughter of the mother".

\section{Manipulating Refrain A: writing the incantation texts}

"Excursions in Refrain A" has shown that the genre was transmitted relatively intact, with most incantation bowls maintaining a uniform sequence particularly in the opening parts. Seven of the texts, BM 91745, BM ${ }^{\mathrm{R}}$ 91720, BM ${ }^{\mathrm{R}}$ 91721, BM ${ }^{\mathrm{R}}$ 91727, IM 9726 and the Pearson and Safani bowls, begin with the Formulae I(a)-(d). The "Rawlinson" group, IM 9726 and the Pearson bowl are all associated with Babylon and were written by two copyists. BM 91713, BM 91758 and AMB B2, which commence with Formulae I(a)-(c), may represent another major tradition within Refrain A, but they lack any provenance information linking them to a particular site. The possibility that regional variants of Refrain A developed in various cities and towns might be raised on the basis of the extract text BM 117883, which came from the British Museum's excavations at Sippar (Abu Habba). However, in this context it is enigmatic that no examples of Refrain A have emerged amongst the large numbers of incantation bowls which have been published to date from Nippur.

Copyists were familiar with a prototype of Refrain A but also exercised considerable flexibility and spontaneity, especially towards the latter parts of the incantation. Composite texts were

${ }^{61} \mathrm{AMB} \mathrm{B} 2$ wšdrw whbylw yth myn 'nyn $d b r(t)$ ' "they sent and injured her (away) from the eyes of the daughter",

${ }^{62}$ See Michael Swartz, "Scribal magic and its rhetoric: formal patterns in medieval Hebrew and Aramaic incantations texts from the Cairo Genizah", Harvard Theological Review 83 (1990) 178 for these formulae ending prayers in the
Jewish liturgy. For Mandaic bowls ending in ' $m$ n see Yamauchi, also BM 91732 and BM 91736 published by Segal. Most Mandaic bowls end with hyy' $z$ 'kyn "Life is victorious".

${ }^{63} \mathrm{BM} 91764$ is composed entirely from this distinctive refrain. 
created by appending other incantations. ${ }^{64}$ IM 9726, the Pearson bowl and BM 91745 add the evocative refrain which commences ql bwlbwl blyly ql trngl' bnghy "the voice of the nightingale at night, the voice of the cock at dawn" ${ }^{65}$ Texts could also be truncated or abbreviated. The Safani bowl terminates midway through the incantation, but coming reputedly from Nevahand in western Iran, this bowl might demonstrate the disintegration of the genre "over time and space" ${ }^{66}$ Harvard Semitic Museum 2036 might present a more advanced example of the disintegration of Refrain A since its text consists essentially a series of binding and sealing clauses, beginning with ' $p y k h$ ' $p y k h$ ' $r$ " 'pykh ' $r$ " "upset, upset is the earth, upset is the earth" ${ }^{67}$ On the other hand, given the popularity of the genre, the opening formula might simply have been appended to another incantation.

Refrain A could be manipulated, but the copyists upheld certain conventions that were particular to this genre. The naming of the client is integral to most incantations,$^{68}$ but does not form part of Refrain $A$, where it is restricted instead to the ancillary elements including the binding and sealing formulae, the preludes and conclusions.

- $\mathbf{B M}^{\mathrm{R}}$ 91720, $\mathbf{B M}^{\mathrm{R}} 91721$ and $\mathbf{B M}^{\mathrm{R}}$ 91727: the client Mahperoz son of Hindo is cited in the binding and sealing formulae that precede and conclude Refrain A, as well as bridging Formulae I(d) and II(a). ${ }^{69}$

- The copyist of $\mathrm{BM}^{\mathrm{R}} 91720$ also wrote within the "inner circle" mryyh rz' dptkry dypkwn mn bytyh wyhpkwn 'l dmpyrwa br hyndw "Lord YY. Mystery of the idol spirits that will go forth from the house - and will overturn against - of Mahperoz son of Hindo".

- BM 91745: the client, Isra son of Amah, is mentioned at the conclusion.

- The Safani bowl commences: mzmn hdyn mylt' l'pwky hršy wm'bdy mn myrdbwk dmtqry myrd' br kwsyg "designated is this spell (lit. word) for the upsetting of sorceries and conjurations from Merdabuch, who is called Merda, the son of Kosig".

- BM 91758 commences with 'swt' myn śmy' lbwsy br grdwšt' "health from heaven for Busy son of Gurdušta".

- The copyist of AMB B2 inscribed several names on the exterior wall of the bowl: $d k y$ ' $b r$

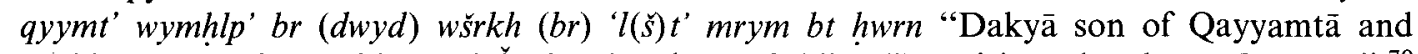
Mahlepā son of (David?) and Šarkā daughter of Alištā(?), Miriam daughter of Horan". ${ }^{70}$ These two males and two females are presumably the clients.

In a distinct break from this convention, the copyist of IM 9726 and the Pearson bowl identified the clients, respectively 'HBTY daughter of MHLPT' and 'YZYD GWŠNS, at various points within the incantation. The text was also adjusted to reflect the client's gender, as follows, IM 9726: 'wpyykh lwtt' d'ym' wbt' $y m^{\prime}$ ' wdmndyr wlwt wšdr 'lh 'htby bt mhlpt' "overturned is the curse of the mother and daughter which is vowed and cursed and sent against 'ḤTY daughter of MHLPT" "; Pearson bowl: 'wpyykh lwtt' hnyn 'ynšh dyndr wlwt wšdr 'lh gwšns "reversed is the curse of these men which is vowed and cursed and sent against Gušnas". ${ }^{71}$ In another exception, not only to the conventions of Refrain A but generally to the "rule of incantations" where human adversaries were seldom cited, ${ }^{72}$ the copyist of BM 91745 wrote the name of the adversary MŠRšY' son of PWRTY within

\footnotetext{
${ }^{64}$ For this process in incantations from the Cairo Genizah, see Swartz, op. cit., 166 where he provides the example of T-S K1.127 and T-S AS 143.487.

65 IM 9726 and the Pearson bowl write $b r b l$ "wolf" and BM $91745 k r b$ ' "cherub" instead of bwlbwl "nightingale".

${ }^{66}$ Yamauchi, op. cit., 514 notes that the Safani bowl came from Nehavand. However, in the absence of any archaeological context, the question of provenance remains open.

${ }^{67}$ See Cyrus Gordon, "Aramaic Incantation Bowls", Orientalia NS 10 (1941) 117-19 [Text 1] = Harvard Semitic Museum, No. 2036. Accession number 899.2.658.

${ }^{68}$ See Philip Alexander, "Incantations and books of magic" in E. Schürer, The History of the Jewish People in the Age of Jesus Christ ( 3 vols. revised and edited by G. Vermes, F. Millar and M. Goodman; Edinburgh, 1986) III:1 354: "The text, which is always careful to name the client or the clients on whose behalf it was written". Swartz,
}

op. cit., 176-7 notes that amulets always included the client's name. For the practice in Syriac Christian amulets see Erica C. D. Hunter, "A scroll amulet from Kurdistan", ARAM 5 (1993) 247.

${ }^{69} \mathrm{BM}^{\mathrm{R}} 91716$ and $\mathrm{BM}^{\mathrm{R}} 91720$ have concluding statements. $\mathbf{B M}^{\mathrm{R}} 91721$ and $\mathrm{BM}^{\mathrm{R}} 91727$ have deteriorated at this point.

${ }^{70}$ Naveh and Shaked, op. cit., 145 mention the names written on the exterior wall of the bowl, commenting that this was unusual since names were usually incorporated within the text and that the text is entirely impersonal. They have not recognised this cardinal feature of Refrain A. On pp. 134-5 they note that the copyist appears to have abandoned the first attempt to write one of the names.

${ }^{71}$ See Hunter, op. cit. (2000), 141 for the text.

${ }^{72}$ Segal, op. cit., 24 where he mentions specifically BM 91745. 
the text and simultaneously adjusted the traditionally feminine gender of the text to the masculine, as follows: qlh dymšr ̌̌y br pwrty dqdh wṣnp wmmll' "the voice of Mešaršiya son of Porti who wails and screams and utters his curse".

The "Rawlinson" group best exemplifies the individualism of the copyists. Despite being the product of one hand, the texts of the four incantation bowls are not identical, and are distinguished by many variants, both minor and major. In $\mathrm{BM}^{\mathrm{R}} 91727$ the copyist omitted any mention of ' $r$ " "the earth", but interpolated $h \breve{s} r y h$ "sorceries" in the listing of elements that were to be overturned. Moreover, the incantation invokes solely the name of Yatba, the angel with eleven epithets, omitting the phrase wbšwm byty'l wyqwty'l "in the the name of Betiel and Yequtiel" that is found in $\mathrm{BM}^{\mathrm{R}} 91720, \mathrm{BM}^{\mathrm{R}} 91721$ and $\mathrm{BM}^{\mathrm{R}}$ 91716. The copyist omitted from $\mathrm{BM}^{\mathrm{R}} 91716$ wkwl dlr' $q r y^{\prime}$ $w k w l$ dlyšmy' msyt' "All that is of the earth calls, and all that is of the heaven obeys", which Naveh and Shaked considered to be the central element of the incantation, from which its efficacy derived. In sum, the textual discrepancies which distinguish the four bowls affirm that the copyist deliberately chose not to reproduce duplicate incantations.

The copyist also elected to arrange the texts differently. Three of the "Rawlinson" group, $\mathbf{B M}^{\mathbf{R}}$ 91720, $\mathrm{BM}^{\mathrm{R}} 91721$ and $\mathrm{BM}^{\mathrm{R}}$ 91727, are written in the typical pattern of Aramaic incantations: i.e. in concentric spirals that begin at the interior centre of the bowl and end at the rim edge. The fourth bowl, $\mathrm{BM}^{\mathrm{R}}$ 91716, was arranged in four self-contained segments, separated by crudely drawn lines but collectively giving the overall appearance of spirals. Segments I, II and IV were written from the centre of the bowl to the rim, but the direction is vice versa in Segment III, where Section I(a) commences five lines from the "inner circle" at the interior centre of the bowl. ${ }^{73}$ As a result, the text appears to have been written and read anticlockwise (Segments III, II, I and IV). The motivation of the copyist in producing this unique arrangement is difficult to discern, but the bowl's intended place of interment might have been the deciding factor. ${ }^{74}$

Orthographic errors and textual variants have also crept into Refrain A, so that even the angels' names were misspelt and the epithet of "YY, the Great, the angel" has no less than five forms. Their occurrence casts interesting light on to the claim made by Michael Swartz in his discussion of amulets from the Cairo Genizah, that "the scribes endeavoured to copy magical names and symbols as accurately as possible, and to follow conventional formulae. However, they distinguished between those names and formulae which had to be followed strictly to make the magic effective, and those literary forms and sequences of themes that could be employed with some flexibility" ${ }^{75}$ These textual inconsistencies and inaccuracies point to the deterioration of Refrain A, but they do not appear to have affected the perceived efficacy of the incantation, in the same way that flaws in the physical fabric of the bowls did not preclude their selection as suitable vessels upon which to pen incantations. ${ }^{76}$ They also suggest that over and above the precise transmission of a text, the act of writing may have been per se the "chief ritual activity", which, together with the recitation of the text, may have ensured the basic function of incantation bowls, namely the protection of the client or clients. ${ }^{77}$

\section{Concluding comments}

There has been much speculation about the ritual of incantation texts and the "magicians" who performed them, but noticeably less discussion about the mechanics of composing and writing incantation texts. ${ }^{78}$ Many issues surrounding the copyists remain as yet unresolved, including the possibility that they may have been women, as well as the question of the commissioning of

\footnotetext{
${ }^{73}$ The incantation text traditionally commenced at this point. For the "inner circle" see Hunter in Segal, op. cit., 171.

${ }^{74}$ The four "Rawlinson" bowls may have been intended for the four corners of the house. See Segal, op. cit., 108-9 for BM 91709.

${ }^{75}$ Swartz, op. cit., 167.

${ }^{76}$ Hunter in Segal op. cit., 169.

${ }^{77}$ Jonathon Smith, "Trading places" in P. Mirecki and
}

M. Meyer (eds.), Magic and Ritual in the Ancient World (Leiden, 2002) 26.

${ }^{78}$ For instance the articles by Jonathan Seidel, "Charming criminals: classification of magic in the Babylonian Talmud"; Michael Swartz, "Magical piety in ancient and medieval Judaism" and Rebecca Lesses, "The adjuration of the Prince of the Presence: performance utterance in a Jewish ritual" in Mirecki and Meyer, op. cit. 
incantations and relationships with the clients for whom the texts were written. ${ }^{79}$ Nevertheless, it would seem that incantations were transmitted orally from generation to generation, from master to apprentice, in time-honoured fashion. ${ }^{80}$ Indeed, as Rebecca Lesses has claimed, "no ruling authority, as far as we know, determined what the formulas should be and there was no process of editing or redaction of the formulas in final form". "Ex "Excursions in Refrain A" shows the degree of improvisation that took place during the transcription of incantations. Within the conventions of the genre, the writing process was flexible and innovative, and the copyists expressed their individuality accordingly.

Their spontaneous expressions impart insight into the Weltanschaunng of incantations. The copyist of $\mathrm{BM}^{\mathrm{R}} 91727$ inserted $h \breve{r} r y h$ "sorceries" after $\check{s} w h w n d k l$ bny 'yš "hour of all mankind" amongst the adverse elements to be overturned. The disassociation from witchcraft and sorcery is again stipulated in $\mathrm{BM}^{\mathrm{R}}$ 91720, where the prelude states 'sryn whtymn kl nydry wlwtt' wptykyr' 'srt' wrwh' byšt' rhyqh ... hšry byšy wm'bdyn byšyn ... wkl $\{m$.$\} mhbryn "bound and sealed be$ all vows and curses and idol spirits, gods and evil spirits, far ... evil witchcraft and evil practices [lit. works] and all sorceries". The demand of $\mathrm{BM}^{\mathrm{R}} 91716, \mathrm{BM}^{\mathrm{R}} 91720$ and $\mathrm{BM}^{\mathrm{R}}$ 91727, that the curses wyzln ' $l$ 'wbdyn w'l mšd(r)nyhwn "shall be returned against the practitioners and those who sent them", is counteractive, but whether any accompanying rituals took place and if so, whether the copyist actually performed them is not divulged. BM $^{\mathrm{R}} 91720$ makes an additional appeal in the "inner circle" of the bowl, as follows: mryyh rz' dptkry dypkwn mn bytyh wyhpkwn 'l dmpyrwz br hynw "Lord YY. Mystery of the idol spirits that will go forth from the house - and will overturn against - of Mahperoz son of Hindo".

Refrain A was a popular incantation especially in the heartland of Mesopotamia, where six bowls are associated with Babylon. It is exceptional in that its adversaries are not the usual repertoire of satans, demons and liliths. ${ }^{82}$ However the texts display little overt rhetoric that would classify them as Jewish, although the names of the angels, Bethiel and Yequtiel, as well as the invocation of YY, "the Great, the angel" and the pious formulae Amen and Selah could point to cultural influence. ${ }^{83}$ The origins of Refrain A are undoubtedly bedded in the greater past of Mesopotamian religion and cult, but as ever the transmission nuances are difficult to discern. Naveh and Shaked remind us that "there are elements which may strike us as Jewish. Some of these have become part of the general non-Jewish magic tradition". ${ }^{84}$ Motifs, formulae and even entire incantation texts passed between the poly-religious communities of Sasanian Mesopotamia. In such a context it would not be surprising to find that both pagans and Jews were familiar with this distinct incantation, a reality that may be echoed by the singular phrase which is present in BM 91713, BM 91758 and AMB B2: byt 'ylhy wbyt knyst' "(in) the temple and the synagogue".

\footnotetext{
${ }^{79}$ Segal, op. cit., 25 claims that the adversaries in Aramaic texts are predominantly female since witchcraft is the occupation of women. He notes the interpolation of $d$ ' $b$ ' in $\mathrm{BM}^{\mathrm{R}} 91727$ and suggests a later date. However, this bowl was one of the "Rawlinson" group and the interpolation was the work of the copyist. For discussion of the attitudes of the Babylonian Talmud and rabbinic sources to "women as witches" see Rebecca Lesses, "Exe(o)rcising power: women as sorceresses, exorcists and demonesses in Babylonian Jewish society of late Antiquity", Journal of the American Academy of Religion 69 (2001) 343-75.
}

${ }^{80} \mathrm{Cf}$. Naveh and Shaked, op. cit., 27.

${ }^{81}$ Lesses, op. cit., 361.

${ }^{82}$ Ibid., 354-9 discusses lilith/s in incantation bowls and rabbinic literature.

${ }^{83}$ See Swartz, op. cit. (1990) for the "rhetoric" of Jewish amulets. Christian "rhetoric" is discussed by Erica C. D. Hunter, "Saints in Syriac anathemas: a form-critical analysis of role", Journal of Semitic Studies 37: 1 (1987) 83-104.

${ }^{84}$ Naveh and Shaked, op. cit., 36. 